\title{
Chuukese Language
}

National Cancer Institute

\section{Source}

National Cancer Institute. Chuukese Language. NCI Thesaurus. Code C153878.

A Trukic language of the Austronesian language family spoken primarily on the islands of Chuuk in the Caroline Islands in Micronesia. 